\title{
Effect Of Theoretical And Institutional Factors On The Adoption Of E-Learning
}

\author{
Mateko Okantey \\ Department of Business Computing \\ Wisconsin International University College, Ghana \\ Hillar Addo, PhD \\ Department of Information Technology studies \\ University of Professional Studies (UPSA), Accra, Ghana
}

doi: 10.19044/esj.2016.v12n16p462 URL:http://dx.doi.org/10.19044/esj.2016.v12n16p462

\begin{abstract}
This paper examined the effect of theoretical and institutional factors that influenced the adoption of e-learning in Universities in Ghana. The study sought to improve understanding of the motivational factors behind the adoption of e-learning systems. This study extended the original Technology Acceptance Model (TAM) to include institutional factors. A sample of 600 lecturers was drawn from both private and public universities in Ghana. Correlation analysis was used to determine the relationship between elearning and the theoretical factors as well as the relationship between elearning adoption and institutional factors. Linear regression analysis was used to determine whether the theoretical factors predict e-learning adoption. The study revealed that e-learning was positively correlated to all the theoretical factors discussed. It was observed that significant relationship existed between Perceived Usefulness (PU) and e-learning, while the weakest relationship existed between e-learning and Perceived Ease of Use (PEOU). The research concluded that a lecturer's adoption of e-learning depended on PEOU as well as PU. However, a lecturer's adoption of elearning was more dependent on a lecturer's PU, that is, the degree to which the lecturer believed that using a particular system would enhance his or her job performance.
\end{abstract}

Keywords: E-learning, adoption, Theoretical factors, Institutional factors, Technology Acceptance Model (TAM)

\section{Introduction}

The growth and expansion of Information and Communication Technologies (ICTs) in education, the progress in adoption and the use of e- 
learning in universities in Ghana is low. In this study an attempt is made to understand the factors that influence this low adoption of e-learning by lecturers, using the Technology Acceptance Model (TAM) to measure the influence of Perceived Ease of Use (PEOU) and Perceived Usefulness (PU), constructs proposed by TAM, in the adoption of e-learning in addition to institutional factors.

E-learning has become a household name in education and its application and use is gradually permeating the education sector globally. It is an important development in education and the new wave strategy comparable with other strategies developed in the wake of the 21st century (Forman, Nyatanga, \& Rich, 2002). Zhang \& Nunamaker (2003) and Tavangarian, Leypold, Nölting, Röser, \& Voigt, (2004), suggested a definition for e-learning, based on the constructivist learning model to include all forms of electronic supported learning and teaching, which are procedural in character and aim to effect the construction of knowledge with reference to individual experience, practice and knowledge of the learner, adding that Information and Communication Systems, whether networked or not, serve as specific media to implement the learning process.

Despite the widespread adoption of computer communications in society, we are yet to fully experience its transformative effect, particularly its effect on e-learning (Garrison, 2011). According to Singh, O'Donoghue, \& Worton, (2005), e-learning could have potentially major effects on the way higher education is designed, implemented and delivered.

There are several behavioural models for explaining the adoption and usage of information technology. These models include the Theory of Reasoned Action (TRA) (Fishbein \& Ajzen, 1975), the Technology Acceptance Model (TAM) (Davis, 1989), the Theory of Planned Behavior (Ajzen, 1985) and several others. In all of these models, the intention to adopt a particular technology is greatly influenced by the perceived usefulness and the ease of use of the technology to the individual user.

Legris, Ingham, \& Collerette, (2003), explained why people use information technology by reviewing articles published from 1980 to the first part of 2001 in periodicals known to include studies on Technology Acceptance Model (TAM). Their research showed that TAM has proven to be a useful theoretical model in helping to understand and explain use behaviour in IS implementation but highlighted an important limitation of TAM in considering IS to be an independent issue in organisational dynamics. Elgort (2005) also explained why e-learning adoption has not reached its full potential in the university despite the wide use of Information and Communication Technology (ICT) in university teaching. He interviewed 59 university staff involved in academic development for elearning from 22 universities in Australia, NZ and the UK. The research 
revealed that the rate of e-learning adoption in their institutions was, at least to some degree, facilitated by the institutional introduction of a Learning Management System (LMS). The effectiveness of any change process relies on the interdependence between the technology, the organisational context, and the change model used to manage the change (Orlikowski \& Hofman, 1997).

In this research, we investigated the factors that influence the adoption of e-learning by lecturers with perceived ease of use and perceived usefulness borrowed from TAM and institutional factors. The institutional factors provide the organizational context for the adoption of e-learning. We determine the extent to which these factors affect the behavioural intention (BI) of lecturers to adopt e-learning towards educational delivery.

This research provides both theoretical and practical contributions. Lecturers and educationists will appreciate the contribution of perceived usefulness and perceived ease of use to their intention to adopt and use elearning. The Technology Acceptance Model (TAM) and other additional factors were tested using a questionnaire distributed to lecturers in various private and public Universities in Ghana. Perceived ease of use and perceived usefulness(PU) have been found to influence Behavioural Intention (BI) and hence adoption of technology. However, e-learning though a form of technology is a service and, therefore, has different characteristics. It might, therefore, be influenced by PU and PEOU differently. Determining the structure of psychological constructs such as "ease of use" and "usefulness" is a complex activity. However, understanding how such concepts behave over varying sets of users and technologies is of critical importance in accurately explaining levels of usage (Segars, \& Grover, 1993). This research is aimed at understanding the reasons behind the low adoption of e-learning in universities using the technology Acceptance Model (TAM) and other factors as perceived by respondents. It was also to measure the effects of factors on the behavioural intention (BI) of lecturers to adopt e-learning through a survey tested and administered to lecturers from particular universities in Ghana.

In the next section of this paper, we present our research model and its theoretical foundation, followed by a description of an empirical study designed to test the proposed model. We then discuss the results and their implications.

\section{Theoretical Development and Research Model}

There are several theories which support the acceptance and adoption of technology in teaching and learning. Most research on adoption and use of technology has relied on the Theory of Reasoned Action (TRA) (Fishbein \&Ajzen, 1975), and other adaptations of this theory. This research seeks to 
use the Technology Acceptance Model (TAM). Davis et al. (1989), which is an adaptation of the Theory of Reasoned Action, in support of our findings from the data analysis. The Technology Acceptance Model (TAM), which is one of the most widely researched models predicting IT adoption, stipulates that perceived usefulness and perceived ease of use determine an individual's intention to use a system with intention to use serving as a mediator of actual system use. Perceived Usefulness (PU) is the degree to which a person believes that using a particular system would enhance his/her job performance (Davis 1989). While perceived ease of use (PEOU) is the degree to which a person believes that using a particular system would be free of effort (Davis 1989). In the context of this research, lecturers will adopt and use e-learning systems if they believe that it will enhance their job performance (Perceived Usefulness) and also that using e-learning systems will be free of effort (perceived ease of use). According to Gefen \& Strab (2000), studies that have investigated self-reported system usage and intended use have found that PU plays a significant role in determining system use. Venkatesh et. al. (2003) have also simplified TAM by removing the attitude construct found in TRA as shown in Figure 1.0.

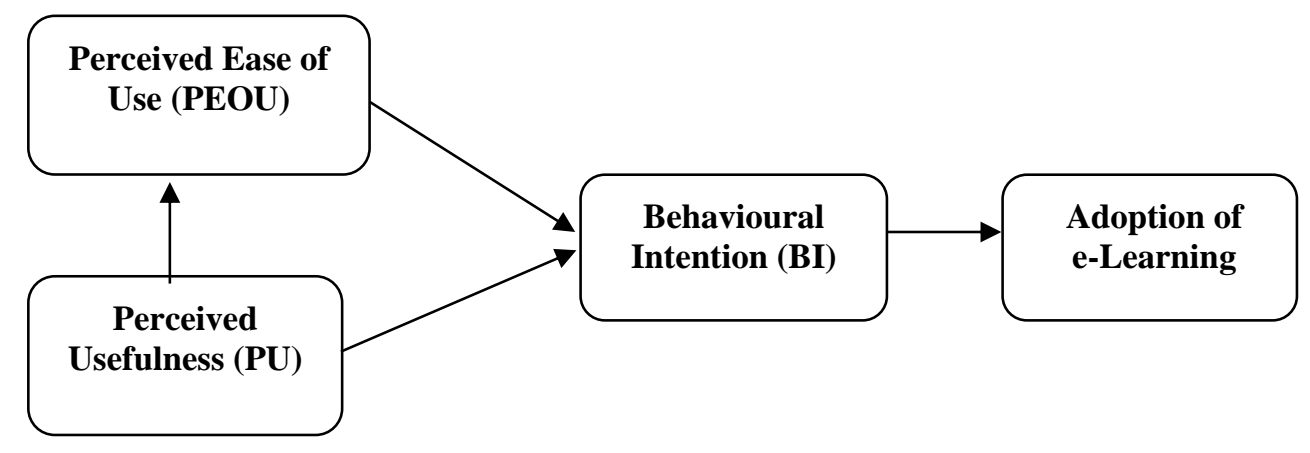

Figure 1.0: Source: Davis et. al. (1989), Venkatesh et. al. (2003)

The current study also examined the influence of the factors deduced (PEOU and PU) on the individual lecturer's behavioural intention to adopt and use e-learning systems.

\section{Methodology}

In order to examine the relationship between the theoretical factors and e-learning adoption, as well as the relationship between institution factors and e-learning adoption, a survey method was used for the study. The required primary data was collected through questionnaire which was developed by the researchers and employed for the purpose of the study. The questionnaires which were the main instrument in this study were put in the 
form of a simple Word document and a web version was developed using google forms. These questionnaires were distributed to respondents by research assistants. The target population was university lecturers in Ghana.

A sample of 600 lecturers was selected from a population of 1800 from both public and private universities in Ghana. The universities were selected using convenience and purposive sampling. This is to allow the study to use samples from universities which were practicing some form of e-learning. After the identification of the universities, stratified and simple random sampling methods were used to select the lecturers from the universities included in the sample. With this technique, each university was treated as a stratum. The number of lecturers selected from each university (strata) was calculated using the sample proportion allocation technique. Out of 600 questionnaires sent to respondents, 540 were retrieved indicating a 90 $\%$ response rate.

Data was collected using rating questions. Questions asked respondents to rate their degree of agreement using a 5-point Likert scale. Respondents responded by indicating whether they strongly disagreed, disagreed, not sure, agreed or strongly agreed to a given statement.

Secondary data for the research was gathered by reviewing existing materials on factors influencing the adoption of e-learning as well as theories of adoption. Information obtained from the secondary sources was used in designing the questionnaire and this information also formed part of the analysis of the survey results. Materials, especially books that were reviewed, have been duly acknowledged in the references.

Statistical Package for Social Sciences (SPSS) was used to analyze the data gathered. Correlation analysis was used to determine the relationship between e-learning adoption and theoretical factors as well as the relationship between e-learning adoption and institutional factors. Linear regression analysis was used to determine whether the theoretical factors predict e-learning adoption.

\section{Effect of Theoretical and Institutional Factors on the Adoption of E- learning}

The goal in this subsection is to examine the relationship between the theoretical factors and e-learning adoption, as well as the relationship between institution factors and e-learning adoption. 


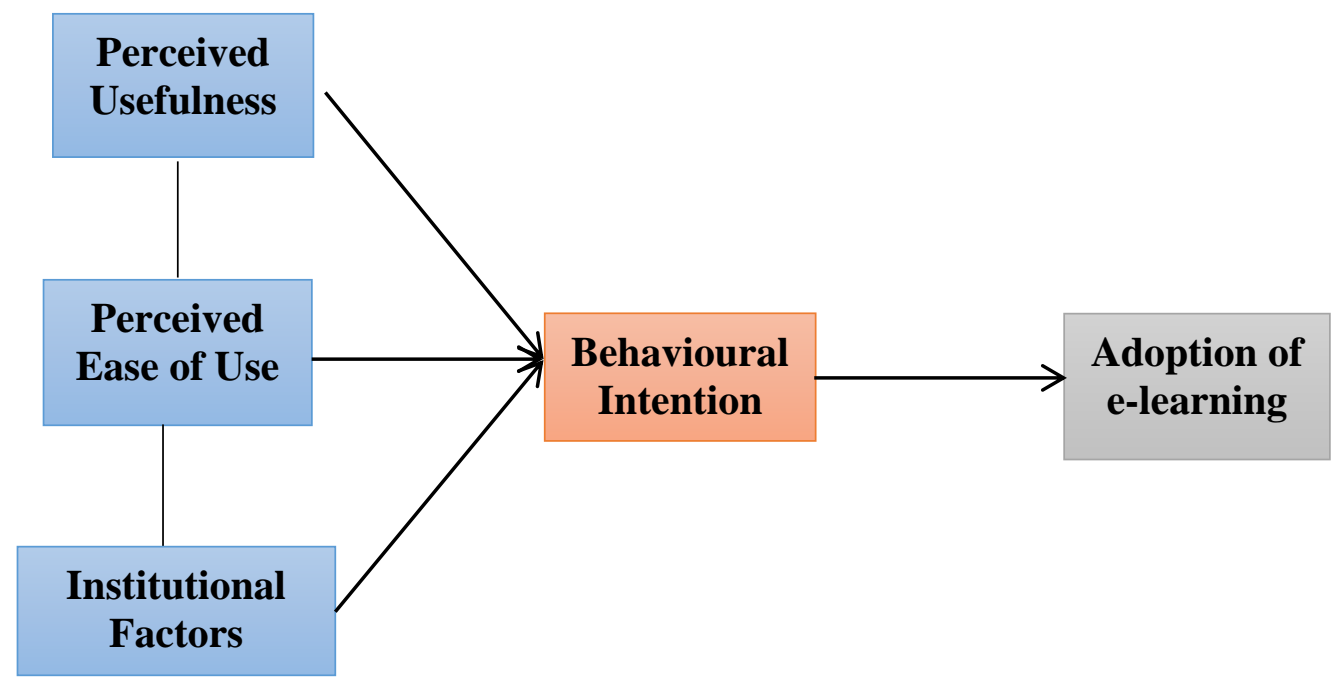

Figure 2.0 Proposed Research Model

Figure 2.0 above is the proposed research model, which includes institutional factors as an influential factor in the adoption of e-learning by lecturers. Institutional factors include leadership directive, policy and the availability of e-learning resources.

Correlation Analysis was used to determine the relationship between the theoretical factors and e-learning adoption, as well as the relationship between institution factors and e-learning adoption.

Table 1: Correlation Matrix - Theoretical Factors and e-learning

\begin{tabular}{|c|c|c|c|c|c|}
\hline & & e-learning & $\begin{array}{l}\text { Perceived } \\
\text { usefulness }\end{array}$ & $\begin{array}{l}\text { Perceived } \\
\text { ease of use }\end{array}$ & $\begin{array}{l}\text { Behavioural } \\
\text { intention }\end{array}$ \\
\hline \multirow{3}{*}{ e-learning } & Pearson Correlation & 1 & $.918^{* *}$ & $.590^{* *}$ & $.780^{* *}$ \\
\hline & Sig. (2-tailed) & & .000 & .000 & .000 \\
\hline & $\mathrm{N}$ & 540 & 540 & 540 & 540 \\
\hline \multirow{3}{*}{ Perceived usefulness } & Pearson Correlation & $.918^{* *}$ & 1 & $.546^{* *}$ & $.757^{* *}$ \\
\hline & Sig. (2-tailed) & .000 & & .000 & .000 \\
\hline & $\mathrm{N}$ & 540 & 540 & 540 & 540 \\
\hline \multirow{3}{*}{ Perceived ease of use } & Pearson Correlation & $.590^{* *}$ & $.546^{* *}$ & 1 & $.620^{* * *}$ \\
\hline & Sig. (2-tailed) & .000 & .000 & & .000 \\
\hline & $\mathrm{N}$ & 540 & 540 & 540 & 540 \\
\hline \multirow{3}{*}{ Behavioural intention } & Pearson Correlation & $.780^{* *}$ & $.757^{* *}$ & $.620^{* * *}$ & 1 \\
\hline & Sig. (2-tailed) & .000 & .000 & .000 & \\
\hline & $\mathrm{N}$ & 540 & 540 & 540 & 540 \\
\hline
\end{tabular}

Table 1 above, shows the correlation between e-learning adoption and the theoretical factors. From the table, e-learning is positively correlated to all theoretical factors: $P U(\mathrm{r}=0.918, \mathrm{p}<.05)$; PEOU $(\mathrm{r}=0.590, \mathrm{p}<.05)$; 
and BI $(r=0.780, p<.05)$. It can be observed that the strongest relationship exists between PU and e-learning, while the weakest relationship exists between e-learning and PEOU. Technically therefore, lecturers' perceived usefulness of e-learning best predicts e-learning adoption.

This section commences a linear regression analysis aimed at finding out whether the theoretical factors predict e-learning adoption.

Table 2: Model Summary - Prediction of e-learning adoption by theoretical factors

\begin{tabular}{|c|r|r|r|r|r|}
\hline Model & \multicolumn{1}{|c|}{$\mathrm{R}$} & R Square & $\begin{array}{c}\text { Adjusted R } \\
\text { Square }\end{array}$ & $\begin{array}{c}\text { Std. Error of the } \\
\text { Estimate }\end{array}$ & Durbin-Watson \\
\hline 1 & $.918^{\mathrm{a}}$ & .842 & .842 & .39873 & \multirow{2}{*}{2.498} \\
\hline 2 & $.927^{\mathrm{b}}$ & .859 & .859 & .37713 & \\
\hline 3 & $.929^{\mathrm{c}}$ & .863 & .862 & .37225 & \\
\hline
\end{tabular}

a. Predictors: (Constant), PU

b. Predictors: (Constant), PU, Behavioural intention

c. Predictors: (Constant), PU, Behavioural intention, Perceived ease of use

d. Dependent Variable: e-learning

Table 2 shows the $R$ Square values of the prediction of e-learning adoption from the theoretical factors. In the table, PU contributes $84.2 \%$ of the total variation on e-learning. Also $\mathrm{PU}$ and $\mathrm{BI}$ contribute a total variation of $85.9 \%$, which means that BI alone accounts for $1.7 \%$ of the total variation. In the third model, PU, BI and PEOU account for $86.3 \%$ of the total variation. Thus PEOU alone accounts for $0.4 \%$ of the total variation. It is evident that PU accounts for the largest amount of variation on e-learning adoption.

According to Sawilowsky (2005), a Durbin-Watson statistic must be close to 2 , if not exactly 2 , or must fall within the range of 1.5 and 2.5 if the independence-of-error assumption is satisfied. In Table 2, the DurbinWatson statistic is 2.498 , a value close to 2 and which falls within the range indicated by Sawilowsky (2005). Hence the independence-of-error assumption is satisfied for the linear regression analysis in which e-learning adoption is hypothetically predicted by the theoretical factors. 
Table 3: Coefficients - Prediction of e-learning adoption by theoretical factors

\begin{tabular}{|c|c|c|c|c|c|c|c|c|c|c|}
\hline \multirow{2}{*}{\multicolumn{2}{|c|}{ Model }} & \multicolumn{2}{|c|}{$\begin{array}{l}\text { Unstandardized } \\
\text { Coefficients }\end{array}$} & \multirow{2}{*}{$\begin{array}{c}\text { Standardized } \\
\text { Coefficients } \\
\text { Beta }\end{array}$} & \multirow[t]{2}{*}{$\mathrm{t}$} & \multirow[t]{2}{*}{ Sig. } & \multicolumn{2}{|c|}{$\begin{array}{c}95.0 \% \\
\text { Confidence } \\
\text { Interval for B }\end{array}$} & \multicolumn{2}{|c|}{$\begin{array}{l}\text { Collinearity } \\
\text { Statistics }\end{array}$} \\
\hline & & B & $\begin{array}{l}\text { Std. } \\
\text { Error }\end{array}$ & & & & $\begin{array}{l}\text { Lower } \\
\text { Bound }\end{array}$ & $\begin{array}{l}\text { Upper } \\
\text { Bound }\end{array}$ & Tolerance & VIF \\
\hline & (Constant) & -.258 & .081 & & -3.180 & .002 & -.418 & -.099 & & \\
\hline 1 & $\begin{array}{l}\text { Perceived } \\
\text { usefulness }\end{array}$ & 1.020 & .019 & .918 & 53.583 & .000 & .983 & 1.057 & 1.000 & 1.000 \\
\hline \multirow{3}{*}{2} & (Constant) & -.715 & .096 & & -7.479 & .000 & -.903 & -.527 & & \\
\hline & $\begin{array}{l}\text { Perceived } \\
\text { usefulness }\end{array}$ & .853 & .028 & .767 & 30.955 & .000 & .799 & .907 & .427 & 2.341 \\
\hline & $\begin{array}{c}\text { Behavioural } \\
\text { intention }\end{array}$ & .286 & .036 & .199 & 8.024 & .000 & .216 & .356 & .427 & 2.341 \\
\hline \multirow{4}{*}{3} & (Constant) & -.777 & .096 & & -8.120 & .000 & -.965 & -.589 & & \\
\hline & $\begin{array}{l}\text { Perceived } \\
\text { usefulness }\end{array}$ & .837 & .027 & .753 & 30.435 & .000 & .783 & .891 & .418 & 2.394 \\
\hline & $\begin{array}{c}\text { Behavioural } \\
\text { intention }\end{array}$ & .230 & .038 & .160 & 6.049 & .000 & .155 & .304 & .366 & 2.733 \\
\hline & $\begin{array}{l}\text { Perceived } \\
\text { ease of use }\end{array}$ & .108 & .028 & .080 & 3.895 & .000 & .053 & .162 & .602 & 1.662 \\
\hline
\end{tabular}

a. Dependent Variable: e-learning

Table 3 above shows the ANOVA results of the prediction of elearning adoption from the theoretical factors. The table shows three models, since the Stepwise Regression Method is used. This analysis is used to verify if the use of regression is a better way of expressing the relationship between e-learning adoption and the theoretical factors. The test is conducted at $5 \%$ significance level. From the table, the test is significant for each model ( $\mathrm{p}<$ .05 ). This indicates that the use of regression is a better way of expressing the relationship between e-learning adoption and the theoretical factors.

Table 3 also shows the coefficients of the prediction of e-learning adoption from the three theoretical factors. In this table, PU significantly predicts e-learning adoption at $5 \%$ significance level $(\mathrm{t}=53.58, \mathrm{p}<.05 ; \beta=$ 1.02). In the second model, PU and BI both significantly predict e-learning adoption at 5\% significance level. In this model, however, the coefficient of PU has reduced from 1.02 to 0.853 . This means that BI influences PU. In the third model, PEOU is introduced, with all theoretical factors significantly predicting e-learning adoption. Yet the introduction of PEOU reduces the $\beta$ coefficients of PU and BI. This situation suggests that PU and BI are influenced by PEOU. Since the VIF (Variance Inflation Factor) score of each predictor is less than 5, the multicollinearity assumption is satisfied. 
Table 4: Excluded Variables - Prediction of e-learning adoption by theoretical factors

\begin{tabular}{|c|c|c|c|c|c|c|c|c|}
\hline \multirow{2}{*}{\multicolumn{2}{|c|}{ Model }} & \multirow{2}{*}{$\begin{array}{c}\text { Beta } \\
\text { In }\end{array}$} & \multirow[t]{2}{*}{$\mathrm{t}$} & \multirow{2}{*}{$\begin{array}{c}\mathrm{p}- \\
\text { value }\end{array}$} & \multirow{2}{*}{$\begin{array}{c}\text { Partial } \\
\text { Correlation }\end{array}$} & \multicolumn{3}{|c|}{ Collinearity Statistics } \\
\hline & & & & & & Tolerance & VIF & $\begin{array}{l}\text { Minimum } \\
\text { Tolerance }\end{array}$ \\
\hline \multirow{2}{*}{1} & $\begin{array}{l}\text { Perceived } \\
\text { ease of use }\end{array}$ & $.128^{\mathrm{b}}$ & 6.472 & .000 & .269 & .702 & 1.424 & .702 \\
\hline & $\begin{array}{l}\text { Behavioural } \\
\text { intention }\end{array}$ & $.199^{\mathrm{b}}$ & 8.024 & .000 & .327 & .427 & 2.341 & .427 \\
\hline 2 & $\begin{array}{l}\text { Perceived } \\
\text { ease of use }\end{array}$ & $.080^{\mathrm{c}}$ & 3.895 & .000 & .166 & .602 & 1.662 & .366 \\
\hline
\end{tabular}

a. Dependent Variable: e-learning

b. Predictors in the Model: (Constant), Perceived usefulness

c. Predictors in the Model: (Constant), Perceived usefulness, Behavioural intention

In Table 4 above, each theoretical factor or predictor has a p-value less than $5 \%$, the level of significance chosen. On the basis of this statistical evidence, no independent variable or predictor is excluded from the regression analysis. Thus each theoretical factor predicts e-learning adoption.

\section{Correlation Between E-learning Adoption and Institutional Factors}

Table 5: Correlation between e-learning and Institutional Factors

\begin{tabular}{|c|c|c|c|c|c|c|}
\hline & & $\begin{array}{c}\mathrm{e}- \\
\text { learning }\end{array}$ & $\begin{array}{c}\text { Institutional } \\
\text { policy }\end{array}$ & \begin{tabular}{|c|} 
Individual \\
initiative
\end{tabular} & $\begin{array}{c}\text { Leadership } \\
\text { directives }\end{array}$ & $\begin{array}{c}\text { Technical } \\
\text { skills }\end{array}$ \\
\hline \multirow{3}{*}{ e-learning } & $\begin{array}{c}\text { Pearson } \\
\text { Correlation }\end{array}$ & 1 & .035 & .000 & .035 & .006 \\
\hline & Sig. (2-tailed) & & .412 & .996 & .423 & .896 \\
\hline & $\mathrm{N}$ & 540 & 540 & 540 & 540 & 540 \\
\hline \multirow{3}{*}{$\begin{array}{l}\text { Institutional } \\
\text { policy }\end{array}$} & $\begin{array}{c}\text { Pearson } \\
\text { Correlation }\end{array}$ & .035 & 1 & .081 & $.757^{* *}$ & $.107^{*}$ \\
\hline & Sig. (2-tailed) & .412 & & .059 & .000 & .013 \\
\hline & $\mathrm{N}$ & 540 & 540 & 540 & 540 & 540 \\
\hline \multirow{3}{*}{$\begin{array}{l}\text { Individual } \\
\text { initiative }\end{array}$} & $\begin{array}{c}\text { Pearson } \\
\text { Correlation }\end{array}$ & .000 & .081 & 1 & $-.167^{* *}$ & $.156^{* *}$ \\
\hline & Sig. (2-tailed) & .996 & .059 & & .000 & .000 \\
\hline & $\mathrm{N}$ & 540 & 540 & 540 & 540 & 540 \\
\hline \multirow{3}{*}{$\begin{array}{c}\text { Leadership } \\
\text { directives }\end{array}$} & $\begin{array}{c}\text { Pearson } \\
\text { Correlation }\end{array}$ & .035 & $.757^{* *}$ & $-.167^{* *}$ & 1 & $.216^{* *}$ \\
\hline & Sig. (2-tailed) & .423 & .000 & .000 & & .000 \\
\hline & $\mathrm{N}$ & 540 & 540 & 540 & 540 & 540 \\
\hline \multirow{3}{*}{$\begin{array}{l}\text { Technical } \\
\text { skills }\end{array}$} & $\begin{array}{c}\text { Pearson } \\
\text { Correlation } \\
\end{array}$ & .006 & $.107^{*}$ & $.156^{* *}$ & $.216^{* *}$ & 1 \\
\hline & Sig. (2-tailed) & .896 & .013 & .000 & .000 & \\
\hline & $\mathrm{N}$ & 540 & 540 & 540 & 540 & 540 \\
\hline
\end{tabular}

Table 5 shows the correlation between e-learning adoption and the institutional factors. From this table, there is a very weak and insignificant 
relationship between e-learning adoption and institutional policy $(\mathrm{r}=0.035$, $\mathrm{p}=0.412)$; individual initiative $(\mathrm{r}=0.000, \mathrm{p}=0.996)$; leadership directives $(\mathrm{r}=0.035, \mathrm{p}=0.423)$; and technical skills $(\mathrm{r}=0.006 ; \mathrm{p}=0.896)$. Therefore it is highly unlikely that the adoption of e-learning is influenced by the institutional factors. Rather, the adoption of e-learning is driven by the theoretical factors. Since the correlations in Table 5 are not significant, no regression analysis is conducted.

\section{Conclusion and Recommendation}

Several theories among which were the Theory of Reasoned Action (TRA) (Fishbein \& Ajzen, 1975), the Technology Acceptance Model(TAM) (Davis, 1989), the Theory of Planned Behavior (Ajzen, 1985) have been used to explain the factors that affect the adoption of a particular technology. This research used the Technology Acceptance Model (TAM) as leverage to examine the effect of the theoretical factors proposed by Davies (1989) on the adoption of e-learning. Some institutional factors were proposed by this research and the effect of these institutional factors on the adoption of elearning was also examined.

The research revealed that e-learning is positively correlated to all theoretical factors. It was observed that the strongest relationship existed between PU and e-learning, while the weakest relationship exists between elearning and PEOU. A very weak and insignificant relationship was, however, observed between e-learning adoption and institutional factors. This is an indication that Perceived ease of use (PEOU) and Perceived Usefulness (PU) are factors that affect the adoption of e-learning with Perceived Usefulness being the most influential factor. This confirms that TAM can be applied in the context of e-learning. Considering the institutional factors, since a very weak and insignificant relationship was observed between the institutional factors and e-learning adoption, we conclude that e-learning adoption is not influenced by institutional factors.

It is recommended that further research should consider the effect of the theoretical and institutional factors on the adoption of e-learning at the pre-teaching, teaching and post-teaching stages.

\section{References:}

Adams, D. A., Nelson, R. R., \& Todd, P. A. (1992). Perceived usefulness, ease of use, and usage of information technology: a replication. MIS quarterly, pp. 227-247.

Ajzen, I (1985). From Intentions to Actions: A Theory of Planned Behavior". Action Control. pp. 11-40.

Davis, F. D. (1989). Perceived usefulness, perceived ease of use, and user acceptance of information technology. MIS quarterly, pp. 319-340. 
Davis, F. D., Bagozzi, R. P., \& Warshaw, P. R. (1989). User acceptance of computer technology: a comparison of two theoretical models. Management science, 35(8), pp. 982-1003.

Elgort, I. (2005, December). E-learning adoption: Bridging the chasm. Proceedings of ASCILITE. pp. 181-185.

Fishbein, M and Ajzen, I. (1975). Belief, Attitude, Intention And Behavior: An Introduction to Theory and Research Reading, Addison-Wesley Publishing Company, 1975.

Forman, D., Nyatanga, L., \& Rich, T. (2002). E-learning and educational diversity. Nurse Education Today, 22(1), pp. 76-82.

Garrison, D. R. (2011). E-learning in the 21st century: A framework for research and practice. Taylor \& Francis.

Gefen, D., \& Straub, D. W. (2000). The Relative Importance of Perceived Ease of Use in IS Adoption: A Study of E-Commerce Adoption. J. AIS, 1, 0. Legris, P., Ingham, J., \& Collerette, P. (2003). Why do people use information technology? A critical review of the technology acceptance model. Information \& Management, 40(3), pp.191-204.

Nagy, A. (2005). The impact of e-learning. E-Content. pp. 79-96.

Orlikowski, W.J., \& Hofman, J.D. (1997). An improvisational model for change management: the case of groupware technologies, Sloan Management Review Winter. pp. 11-21.

Singh, G., O'Donoghue, J., \& Worton, H. (2005). A study into the effects of elearning on higher education. Journal of University Teaching \& Learning Practice, 2(1), p. 3.

Segars, A. H., \& Grover, V. (1993). Re-examining perceived ease of use and usefulness. MIS quarterly, 17(4), 517-525.

Tavangarian, D., Leypold, M. E., Nölting, K., Röser, M., \& Voigt, D. (2004). Is e-learning the Solution for Individual Learning? Electronic Journal of Elearning, 2(2), pp. 273-280.

Tzeng, G. H., Chiang, C. H., \& Li, C. W. (2007). Evaluating intertwined effects in e-learning programs: A novel hybrid MCDM model based on factor analysis and DEMATEL. Expert systems with Applications, 32(4), pp.1028-1044.

Venkatesh, V., Morris, M. G., Davis, G. B., \& Davis, F. D. (2003) User Acceptance of Information Technology: Toward a unified view. MIS Quarterly 27(3), pp. $425-478$

Venkatesh, V., \& Davis, F. D. (1996). A model of the antecedents of perceived ease of use: Development and test. Decision sciences, 27(3), pp. 451-481.

Welsh, E. T., Wanberg, C. R., Brown, K. G., \& Simmering, M. J. (2003). Elearning: emerging uses, empirical results and future directions. International Journal of Training and Development, 7(4), 245-258. 
Zhang, D., \& Nunamaker, J. F. (2003). Powering e-learning in the new millennium: an overview of e-learning and enabling technology. Information Systems Frontiers, 5(2), pp. 207-218. 